\title{
The Rise of 3D in Maritime Archaeology
}

\author{
John McCarthy, Jonathan Benjamin, Trevor Winton, \\ and Wendy van Duivenvoorde
}

\begin{abstract}
This chapter provides an overview of the rise of 3D technologies in the practice of maritime archaeology and sets the scene for the following chapters in this volume. Evidence is presented for a paradigm shift in the discipline from 2D to 3D recording and interpretation techniques which becomes particularly evident in publications from 2009. This is due to the emergence or improvement of a suite of sonar, laser, optical and other sensor-based technologies capable of capturing terrestrial, intertidal, seabed and sub-seabed sediments in 3D and in high resolution. The general increase in available computing power and convergence between technologies such as Geographic Information Systems and 3D modelling software have catalysed this process. As a result, a wide variety of new analytical approaches have begun to develop within maritime archaeology. These approaches, rather than the sensor technologies themselves, are of most interest to the maritime archaeologist and provide the core content for this volume. We conclude our discussion with a brief consideration of key issues such as survey standards, digital archiving and future directions.
\end{abstract}

\section{Keywords}

3D applications $\cdot 3 \mathrm{D}$ reconstruction $\cdot 3 \mathrm{D}$ mapping ·

Shipwrecks $\cdot$ Submerged landscapes $\cdot$ Marine survey

J. McCarthy $(\bowtie) \cdot J$. Benjamin · T. Winton · W. van Duivenvoorde Maritime Archaeology Program, Flinders University,

Adelaide, SA, Australia

e-mail: john.mccarthy@ flinders.edu.au; jonathan.benjamin@

flinders.edu.au; wint0062@ flinders.edu.au; wendy.

vanduivenvoorde@flinders.edu.au

\section{$1.1 \quad$ Background}

The need for a volume focused on the use of 3D technologies in maritime archaeology has become increasingly apparent to practitioners in the field. This is due to an exponential increase in the application of several distinct 3D recording, analysis and interpretation techniques which have emerged and become part of the maritime archaeologist's toolbox in recent years. In November of 2016, a workshop on this theme was hosted by the UNESCO UNITWIN Network for Underwater Archaeology and Flinders University, Maritime Archaeology Program, in Adelaide, South Australia. The UNITWIN Network (2018) is a UNESCO twinning network of universities involved in education and research of maritime and underwater archaeology. The criteria for full membership requires that each university must offer a dedicated degree in maritime or underwater archaeology. Membership (full and associate members) of the Network currently stands at 30 universities worldwide and the network continues to grow as more universities with existing courses are added. Flinders University chaired the Network as its elected Coordinator (2015-2018), which was passed on to Southampton University at the end of 2018. The workshop in Adelaide and this publication have been undertaken in line with the objectives of the UNITWIN Network which include promotion of 'an integrated system of research, training, information and documentation activities in the field of archaeology related to underwater cultural heritage and related disciplines.' A major element of the workshop was group discussion and many participants in the workshop noted an urgent need for stronger communication and collaboration between maritime archaeologists working in the areas of 3D applications. This volume was inspired by the group discussions held at the workshop and is the first collection of studies devoted exclusively to discussion of 3D technologies for maritime archaeology. As such it is hoped that it will make an important contribution towards fulfilling the aims of the Network. 


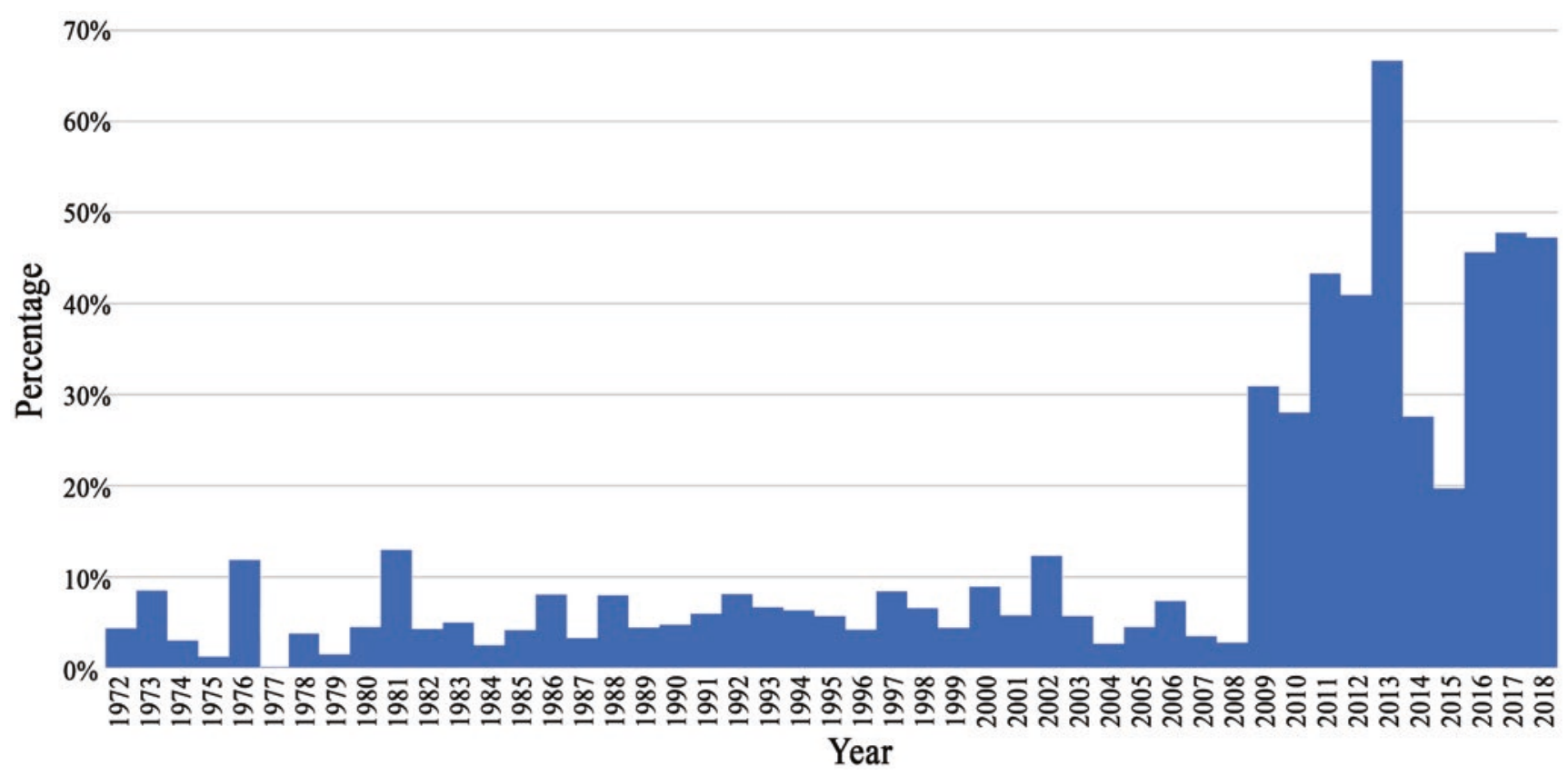

Fig. 1.1 The percentage of International Journal of Nautical Archaeology (IJNA) articles by year which mention the phrase 3D or related variations, from 1972 to mid-2018

The recent and rapid adoption of 3D techniques is well known by practitioners of maritime archaeology but can be illustrated for those outside the discipline by tracing use of the term 3D and related variants in papers published in the International Journal of Nautical Archaeology (IJNA). As the longest running periodical focused on maritime archaeology (founded in 1972) a review of the IJNA serves as a useful indicator of activity in the field. A search was undertaken of all IJNA articles (including references) using the citation analysis software Publish or Perish (Harzing 2007), which draws on the Google Scholar database. The search covered the period 1972 to mid-2018 and returned 466 published articles that include the term 3D (or similar variants) from a total of 3400 articles. A breakdown by year demonstrates clearly that use of the term in the journal was consistently low from the first edition up to 2009 when values jumped from roughly $6 \%$ to over $20 \%$, up to a maximum of $65 \%$. While some of these articles may only mention 3D applications in passing, this nevertheless illustrates a noteworthy step change within the discipline (Fig. 1.1).

\subsection{The Importance of 3D for Maritime Archaeology}

The general shift towards greater use of 3D sensors and workspaces is not exclusive to archaeology and can be seen in many other disciplines. Although archaeology encompasses many different perspectives and approaches, it is, by definition, grounded in the physical remains of the past. A standardized 2D record has been the accepted standard for recording sites during the twentieth century. This includes the production of scaled plans in which the third dimension was indicated using symbolic conventions, such as spot heights and hachure lines. Such outputs remain in use but as 3D surveys have become more popular there is increased recognition that flattening of an archaeological feature creates more abstraction (Campana 2014; Morgan and Wright 2018). This leads to some interesting debates on the tensions between capturing the most accurate and objective surveys possible and the archaeologist's ultimate goal of cultural interpretation. So successful has been the research on highresolution 3D sensors for maritime archaeology in the last decade that Drap et al. (Chap. 9) can now state that 'In a way, building a 3D facsimile of an archaeological site is not itself a matter of archaeological research even in an underwater context.' Menna et al. (2018) have provided an overview of the main passive and active sensors generating 3D data for maritime archaeology at present, categorized with respect to their useable scale, depth and applicable environment, with a list of key associated publications for each. There will always be a need for research into technical improvements in 3D survey techniques but research into new analytical techniques founded upon these 3D survey datasets is just beginning. The chapters in this volume demonstrate this in a wide variety of innovative and exciting ways.

Broadly, maritime archaeology is the study of the human past, through material culture and physical remains, that specifically relate the interaction between people and bodies of water and there are numerous factors that make data capture 
and analysis in 3D particularly important to the maritime archaeologist. There is a greater reliance upon recording techniques that capture data quickly in maritime archaeology (Flatman 2007, 78-79), especially in subaquatic environments where maritime archaeology fieldwork often occurs. This is mainly because of the cost of vessels and equipment, as well as the fact that divers can spend only short periods of time under water. Until recently, maritime archaeologists working in complex underwater surveys or excavations had to rely almost entirely upon difficult and time-consuming manual techniques. A single measurement required a diver to swim around the site taking several tape measurements from datums to obtain a single position (Rule 1989). This manual approach still has a place; however, since 2006, high resolution 3D capture has increasingly become the first choice of survey method for wrecks underwater, using both sonar and photogrammetric techniques. Of the sonar techniques, the use of high resolution multibeam has allowed 3D capture of vast areas of the seabed in $3 \mathrm{D}$ at resolutions of up to a metre and of individual exposed wrecks at much higher resolutions. Demonstration of the value of high resolution multibeam for wrecks was perhaps first clearly demonstrated by the RASSE (Bates et al. 2011) and ScapaMap projects (Calder et al. 2007), described as 'the most influential in illustrating the potential for multibeam in archaeology and the most pertinent to multibeam use for deepwater shipwreck studies' (Warren et al. 2010, 2455). Multibeam data are increasingly gathered on a national scale by governmental agencies and often made available to maritime archaeologists to underpin their site-specific studies. Work on the Scapa wrecks continues with demonstration of extremely high-quality survey and visualization for large metal wrecks (Rowland and Hyttinen 2017).

Representing another step change in 3D recording, underwater photogrammetry is now capable of highly detailed surveys of large wreck standing well above the seabed. Good examples include the Mars Project-involving comprehensive 3D survey of an incredibly well-preserved shipwreck in the Swedish Baltic (Eriksson and Rönnby 2017) and the Black Sea Project-where deep-sea ROVs are being used to 3D survey some of the oldest intact shipwrecks ever discovered (Pacheco-Ruiz et al. 2018). Photogrammetry even facilitates 3D survey of the spaces inside large vessels, as demonstrated by the early results of the Thistlegorm Project (2018) - a comprehensive survey in 3D of one of the most well-known and dived wrecks in the world. Other important 3D sensing techniques for the marine environment also emerged around the same time, including lidar bathymetry (Doneus et al. 2013, 2015), 3D sub-bottom profilers (Gutowski et al. 2015; Missiaen et al. 2018; Plets et al. 2008; Vardy et al. 2008) and Electrical Resistivity Tomography (ERT) (Simyrdanis et al. 2016; Passaro et al. 2009; Ranieri et al. 2010; Simyrdanis et al. 2015, 2018). These are enor- mously important due to their ability to non-invasively recover 3D data from shallow water (lidar bathymetry) sites and from below the seabed (sub-bottom profilers and ERT), but due to cost and availability are not nearly as widely used as multibeam and photogrammetry. On a final note regarding terminology, Agisoft rebranded Photoscan as Metashape with the release of Version 1.5 at the end of 2018. In order to avoid confusion, the term 'Photoscan/Metashape' is used throughout this volume for all versions.

\subsection{Photogrammetry}

One of the most rapidly adopted and widely used techniques photogrammetry, or Structure from Motion, is now frequently applied to record archaeological material underwater-it is worth pausing here for a more detailed look at the impact of the technique. Underwater survey of complex features is a frequent task for maritime archaeologists, who aim to achieve a standard of recording equal to terrestrial site investigations. Excavations at Cape Gelidonya (Bass et al. 1967) are often described as the first attempt to apply this standard. For some detailed wreck excavations, achieving this standard has required an investment of time and money that far exceeds terrestrial excavation, particularly for deep wreck sites. The excavation and survey dives required for the wreck at Uluburun reached a total of 22,413 dives to depths of between $44 \mathrm{~m}$ and $61 \mathrm{~m}$ (Lin 2003, 9), with all the attendant cost and risk that goes with such high figures. Since it is possible to carry out high quality photography under water, it is understandable that the potential to recover measurements from photographs should have been of interest from the earliest underwater surveys. Despite some successes in the earliest experiments by underwater archaeologists (Bass 1966), the use of photogrammetry failed to generate significant levels of interest for the first 30 years of the discipline as it remained technical and time consuming (Green 2004, 194-202). Outside of archaeology, major developments in algorithms and mathematical models were slowly accruing in the field of photogrammetry (Micheletti et al. 2015, 2-3), eventually leading to the advent of automated software packages that removed much of the overhead for technical knowledge. These software packages were created for use in terrestrial contexts, but scientific divers quickly realized that they could be applied underwater with some simple adaptations (McCarthy and Benjamin 2014). There has been a flurry of publication in maritime archaeology (Menna et al. 2018, 11-14), much of which has focussed exclusively on the technical challenges of achieving higher quality and accuracy. Photogrammetry has also been extremely effective for archaeological survey when used with multi-rotor aerial drones, which first began to make an impact in archaeological publication circa 2005 
(Campana 2017, 288). Paired with software such as Photoscan/Metashape and Pix4D from 2011, drones have become effective tools for coastal, intertidal and even shallow water survey for maritime archaeology (see Benjamin et al. Chap. 14 for a more detailed discussion).

A brief note on terminology for photogrammetry is necessary as it is a broad term. Defined by the Oxford English Dictionary (2018) as 'the use of photography in surveying and mapping to ascertain measurements between objects' photogrammetry has been in use as a mapping technique since the mid-nineteenth century, primarily from airborne cameras. The modern convergence of different technologies and workflows from various disciplines utilising photogrammetry at close range has created confusion in terminology within maritime archaeological publications (McCarthy and Benjamin 2014, 96). The rise of highly automated and integrated software packages such as Visual SfM, Photoscan/ Metashape, Reality Capture, PhotoModeler, Pix4D and Autodesk's ReCap software, although built on the same principles as 'traditional photogrammetry' are far more automated and produce a high-resolution 3D model with little or no operator intervention. As a result, they have a much greater impact on the discipline of archaeology and related sciences. It is necessary to differentiate these types of workflow from previous techniques, but several competing terms have been used in parallel, even by the same researchers. The term 'automated photogrammetry' (Mahiddine et al. 2012) has been used by some, in recognition of the much higher degree of automation in these workflows. Unfortunately, this can be confusing as there have been many incremental steps toward automation of photogrammetry prior to the appearance of these software packages. One of the most widely used terms at present is 'computer vision' (Van Damme 2015a; Yamafune 2016), the most detailed defence of which in the field of maritime archaeology is provided by Van Damme (2015b, 4-13). Computer vision and photogrammetry are converging technologies - the subtle difference, however, is that photogrammetry has a greater emphasis on the geometric integrity of the 3D model. Others have used 'multi-image photogrammetry' (Balletti et al. 2015; McCarthy 2014; McCarthy and Benjamin 2014; Yamafune et al. 2016) as earlier applications of photogrammetry have been mainly based on use of stereo pairs. Another popular term appearing with increasing frequency in the literature is Structure from Motion (SfM). Remondino et al. $(2017,594)$ define SfM as a two-step process 'a preliminary phase where $2 \mathrm{D}$ features are automatically detected and matched among images and then a bundle adjustment (BA) procedure to iteratively estimate all camera parameters and 3D coordinates of 2D features.' While this definition covers the core of the process used within these software packages and has a strong analogy to traditional photogrammetry, SfM does not necessarily cover the process of meshing or texturing commonly applied at the end of the workflow.
In practice, the umbrella term 'photogrammetry' appears to have become the most popular term in archaeology to refer to this specific approach, because other types of photogrammetry are now far less commonly used by practicioners. Due to a lack of consensus at present, the editors of this volume have deliberately not attempted to standardize use of the term across the chapters. In contrast, the use of the form ' $3 \mathrm{D}$ ' has been adopted over alternatives such as '3-D' or 'three dimensional' throughout, following the argument by Woods (2013).

\subsection{Beyond Survey}

Contributors to this volume have demonstrated meaningful results using both simple approaches, from use of 3D scan data to undertake volumetric calculations, through to complex approaches such as use of machine learning. In addition to enhanced levels of prospection and survey, there are an increasing variety of new possibilities opening up as a result of advances in 3D analysis for ship and aviation wrecks. In part, this is driven by general rise in available computing power and an ongoing convergence between technologies such as Geographic Information Systems and 3D modelling software. This has encouraged use of 3D software in a general way. Tanner (2012) provides a good example of this through the use of 3D scans to calculate hydrostatic performance of vessels.

Some authors have demonstrated simple and effective analytical applications for 3D data. Semaan et al. (Chap. 5) demonstrate use of photogrammetric surveys of stone anchors to make more accurate assessments of their volume, offering insights into vessel size. A particularly interesting application of photogrammetry for maritime archaeology is the use of legacy photogrammetry data; using old photographs to generate 3D data. While there has been at least one example of this in terrestrial archaeology (Discamps et al. 2016), suitable photographic datasets are hard to find in the archives as there are rarely enough photographs of archaeological subjects with sufficient coverage and overlap to process in this way. Maritime archaeologists, however, have relied heavily on orthomosaic photography since the first surveys of underwater wrecks in the 1960s. Even as a manually overlapped patchwork of separate prints, photos provided important additional details once the archaeologist was back on dry land. As a result, there are likely to be many opportunities to revisit these datasets. Green has done just this (Chap. 3), reprocessing vertical photos from two shipwreck excavations undertaken in 1969 and 1970. The quality of the results suggests an enormous future potential for similar work and for new insights based on this recovered 3D data. Hunter et al., in their contribution (Chap. 6), consider whether a similar approach might be useable for single 
images. In their chapter, several historical photos of a ship taken throughout the course of its lifetime are used to generate a 3D model of the changing ship through a semi-automated process that provides new insights into the life of a historical shipwreck.

Public dissemination represents a major opportunity for 3D technologies to enhance maritime archaeology. The sharing of 3D survey data and of reconstructions in 3D has a particular appeal for maritime archaeology, as the majority of the public are not divers. Many sections of society cannot experience shipwrecks in person, for many reasons including opportunity, physical capacity and financial factors. The potential of 'virtual museums' for maritime archaeology was first discussed by Kenderdine (1998) but the first substantial projects did not begin until around 2004 (Adams 2013, 93-94) and interest continues to grow (Alvik et al. 2014; Chapman et al. 2010; Drap et al. 2007; Haydar et al. 2008; Sanders 2011). The iMareCulture (2018) project is amongst the most substantial current developments; the EU-funded collaboration between 11 partners in 8 countries, integrates archaeological data into virtual reality and further advances the practice by gamifying the experience (Bruno et al. 2016, 2017; Liarokapis et al. 2017; Philbin-Briscoe et al. 2017; Skarlatos et al. 2016). Woods et al. provide an excellent example of virtual reality for maritime archaeology in this volume (Chap. 13), with one of the most comprehensively captured maritime landscapes yet released. Crucially, this project demonstrates impact via its wide dissemination to the public through a variety of interactive and virtual reality platforms. Another emerging 3D dissemination strategy is the use of online 3D model sharing platforms (Galeazzi et al. 2016). Both Europeana (2018), the EU digital platform for cultural heritage, and the popular Sketchfab (2018) website, began their 3D model hosting services in 2012. While Sketchfab does not conform to archaeological digital archiving standards, it has proven popular and hosts 3D models of hundreds of professional and avocational maritime archaeological sites and objects. Firth et al. (Chap. 12) volume demonstrate the potential power of simple tools like Sketchfab have when combined with professional archaeological input, in this case combining scans of a builder's scale model with high resolution multibeam survey of the wreckage of the same First World War ship_-an outlet that has so far achieved over 20,000 views.

Given the widespread use of superficially realistic pseudohistorical animations and simulations in popular culture, particularly in film and television (Gately and Benjamin 2018), it is critical that genuinely researched outputs, based on archaeological data and created for educational purposes, have transparent and scientifically grounded authenticity. The chapter by Suarez et al. (Chap. 8) on procedural modelling for nautical archaeology offers one potential solution in this regard for, as noted by Frankland and Earl (2012, 66), 'the interpretive process an archaeologist undergoes whilst creating a reconstruction using procedural modelling is recorded and made explicit.' In other words, every interpretation and assumption made by the archaeologist is codified as a rule in the procedure used to generate the final model, and may in theory, be deconstructed or modified in light of new evidence. Suarez et al.'s chapter is one of the most developed attempts to apply procedural modelling in the field of archaeology to date and demonstrates the enormous potential for this approach to change the way we approach historical ship reconstruction (Chap. 8).

For submerged landscape applications, working in 3D offers major benefits. 'To create a useful maritime archaeological landscape formation model, archaeological space and time must be analysed in three dimensions, including the surface and water column in addition to the sea floor' (Caporaso 2017, 17). After all, the study of submerged prehistory is reliant on landscape change over time, sea-level change, geomorphology and sediment modelling. There, it is necessary to understand site formation processes when prospecting for submerged archaeological sites. This has been demonstrated in the Southern North Sea (Gaffney et al. 2007) where 3D deep seismic survey gathered by the oil industry was used to model a vast submerged landscape which would have been occupied by Mesolithic Europeans. In researching a submerged archaeological site, the modern sea level imposes a division of the landscape that can interfere with the archaeologist's interpretation of that site. Through an integrated suite of 3D technologies, this division can effectively be erased. This has been amply demonstrated by the work undertaken at the submerged Greek settlement of Pavlopetri (Henderson et al. 2013; Johnson-Roberson et al. 2017; Mahon et al. 2011) where detailed reconstructions of the city have been extrapolated from wide-area 3D photogrammetric survey. In this volume, the chapter by Benjamin et al. (Chap. 14) also demonstrates this through a series of case studies, culminating in a submerged Mesolithic landscape captured in 3D across and beyond the intertidal zone. This chapter addresses the critical issue of theory in the discipline and asks how these new tools are influencing the way we engage with Maritime Cultural Landscapes, providing a much-needed balance to a volume that is necessarily centred on technology.

As well as facilitating long-term accurate monitoring of maritime archaeological sites over time, 3D geophysical techniques offer far more detailed non-destructive surveys of shallow-buried archaeological material. Article 2 of the 2001 UNESCO Convention on the Protection of the Underwater Cultural Heritage prioritizes in situ preservation. Although still not widely available, there have been a few projects that have demonstrated sub-seabed surveys in estuarine and coastal locations in high resolution 3D without the need for excavation. Perhaps the earliest example is by Quinn et al. 
(1997) who published the geophysical evidence for paleoscour marks at the Mary Rose site. Subsequent technical evolution of 3D sub-bottom profiling systems, include a 3D Chirp reconstruction of the wreck of Grace Dieu (Plets et al. 2008, 2009) and Missiaen et al's (2018) parametric 3D imaging of submerged complex peat exploitation patterns. Two further ground-breaking studies on this subject appear in this volume. Winton's chapter on James Matthews also uses a parametric sub-bottom profiler to build up a detailed model of a previously excavated and reburied wreck, allowing a quantitative assessment of data quality (Chap. 10). In a similar way, the chapter by Simyrdanis et al. (Chap. 11) demonstrates a new technology using Electrical Resistivity Tomography to recover the shape of a buried vessel in a riverine context. These chapters clearly demonstrate the future importance of this approach. It is also telling that both chapters have been able to incorporate use of 3D reconstructions of their vessels.

\subsection{Future Directions}

A comprehensive review of all 3D technologies likely to become part of maritime archaeology is beyond the scope of this chapter, though some of the techniques with significant potential are highlighted. In the concluding section of the Oxford Handbook of Maritime Archaeology, Martin (2011, 1094) considers the trajectory of maritime archaeology and asked whether the role of the diver was threatened by advances in remote sensing. In another chapter of the handbook, Sanders (2011) speculated that we might soon be wearing 'location-aware wearable computers linked to a 3D-based semantic Internet with the capability of projectionholographic imagery of distant, hard-to-access, or lost maritime sites.' Since those words were written they have already come partly true through the rise of the internet-linked GPSenabled smartphones and portable virtual and augmented reality headsets. Indeed, augmented reality has enormous potential for maritime archaeology through the use of augmented displays for scientific divers (Morales et al. 2009).

It is easy to see the potential benefits of overlaying sonar and photogrammetric models of underwater archaeological sites on the diver's vision, particularly in low visibility. Augmented and virtual reality systems may also help to give the non-diving public an immersive experience of exploring underwater sites, perhaps even while in a swimming pool (Yamashita et al. 2016). Management of maritime archaeological sites will certainly be facilitated by these new technologies. Effective in situ management requires a priori 3D information to identify lateral extent, height and/or depth of burial of archaeological material on the site, their material type and state of deterioration. In terms of more accurately understanding site formation processes, Quinn and Boland (2010) demonstrated how multiple fine-scale 3D bathymetric models can be used in time lapse sequence and Quinn and Smyth (2017) showed how 3D ship models can be incorporated into sediment scour analyses. The cost of high quality $3 \mathrm{D}$ survey is now at the point that it is likely that states will begin to develop $3 \mathrm{D}$ versions of their national inventories of maritime archaeological sites. Radić Rossi et al. in this volume present ground-breaking work on a sixteenth-century wreck in Croatia (Chap. 4), where 3D survey has been used to generate $2 \mathrm{D}$ plans, site condition has been monitored in $3 \mathrm{D}$ over multiple field seasons and the archaeological remains have been fitted to a 3D reconstruction of the vessel.

In his consideration of the future of photogrammetry for underwater archaeology, Drap et al. (2013) highlighted a number of future applications of the technology, including the merging of data from optic and acoustic sensors and has stated that once the technical challenge of high resolution and accurate survey was overcome, the 'main problem now is to add semantic to this survey and offering dynamic link between geometry and knowledge' and at that stage suggested that pattern recognition and the development of ontologies would be key steps (Drap et al. 2013, 389). In a wide-ranging contribution to this volume, Drap et al. develop these ideas further, including use of virtual reality, the application of machine learning to the recognition of archaeological objects visible in the 3D survey data and experimentation with 3D reconstruction from single images.

\subsection{Standards}

The wave of technological innovation has occurred in such a short space of time that knowledge sharing through publication has often proved inadequate, with many practitioners developing workflows in relative isolation from their peers. While this has led to a flowering of experimentation and innovation and is part of the natural process of technological change, it has also caused duplication, wasted effort and a general sense of a discipline working in unconnected silos. A greater problem is that the adoption of these new workflows risks seducing the discipline away from the rigorous standards using traditional recording techniques, which have developed over many decades.

To some extent the approach toward standardization will vary by technique and will depend on whether maritime archaeologists work with technical specialists or whether an attempt is made to make a technique part of their own workflow. This echoes the early debate on whether archaeologists should train as divers or vice versa (Muckelroy 1978, 30-32). Some techniques such as bathymetric lidar survey are likely to remain within the hands of highly specialized technicians, while the simple nature and low cost of photogrammetry means that many archaeologists have taken it entirely into their own hands. This technique, however, has many hidden 
complexities and Huggett (2017) has highlighted the potential danger of blind reliance on technologies that processes and transform data in ways not generally understood by the user.

As Remondino et al. $(2017,591)$ state 'nowadays many conferences are filled with screenshots of photogrammetric models and cameras floating over a dense point cloud. Nonetheless object distortions and deformations, scaling problems and non-metric products are very commonly presented but not understood or investigated.' A small number of guidance documents have begun to appear for photogrammetry. Perhaps the most detailed in the English language for capture using current techniques is that by Historic England, which includes case studies for maritime archaeology (Historic England 2017, 102-106). This guidance includes important sections on the use and configuration of control networks, calculation of accuracy as well as formats and standards for archiving of digital data.

Austin et al. (2009) have written guidance for marine remote sensing and photogrammetry, focused mainly on data management and archiving, although this is already quite dated after less than a decade. At the time of writing, there is no detailed formal guidance focused on underwater photogrammetry. While most of the important information is available in journal publications, such sources tend to present case studies with specific workflows which are still experimental in many ways. Shortis, who has been heavily involved in the development of photogrammetry for scientific recording, has provided a chapter for this volume that discusses these issues (Chap. 2). Numerous authors have also highlighted the risks of disruption of archiving standards in this period of rapid transition to digital technologies (Austin et al. 2009; Jeffrey 2012). One possible solution to this challenge is the publication of supplementary digital data alongside academic papers (Castro and Drap 2017, 46) and the International Journal of Nautical Archaeology has taken the first step in this direction by publishing an online 3D model alongside an article (Cooper et al. 2018). A similar facility has also been offered to the authors of the current volume. While not a complete solution equivalent to a national infrastructure for comprehensive digital archiving, this approach does provide an improved record of digital archaeological investigations compared to a 2D publication and this will facilitate further reuse and reinterpretation of data.

\subsection{Conclusions}

The timing of the great leap in interest in 3D seen in IJNA articles from 2009 onwards can be correlated with the introduction or maturation of several different 3D survey techniques and 3D dissemination tools. Some of these had a long history, such as photogrammetry, but had evolved from niche technical forms into accessible tools with wide appeal. After several decades of relatively incremental refinement of manual and low-resolution survey methods, and highly abstracted and symbolized 2D modes of analysis and dissemination, a watershed has been reached in the last decade whereby maritime archaeology has rapidly added 3D digital practices to its core toolbox. The need for enhancements of these survey techniques (as well as research into new technologies) continues, however, high-resolution data capture in 3D is now possible across submerged, terrestrial and coastal, marine and freshwater environments both shallow and deep. Practitioners are developing a fluency in 3D working practices to deal with these datasets and this has led to a flowering of different analytical approaches that were not possible in the past. The review of changes in the past decades suggests that it would be foolhardy to predict the future direction of technologies but it is clear that changes will continue. If anything, advances are likely to accelerate. It is more important than ever that practitioners defend the discipline's scientific status, through the maintenance of standards as they relate to recording, analysis, interpretation, dissemination and archiving of archaeology in 3D.

\section{References}

Adams JR (2013) Experiencing shipwrecks and the primacy of vision. In: Adams JR, Ronnby J (eds) Interpreting shipwrecks: maritime archaeological approaches. The Highfield Press, Southampton, pp 85-96

Alvik R, Hautsalo V, Klemelä U, Leinonen A, Matikka H, Tikkanen S, Vakkari E (2014) The Vrouw Maria underwater project 2009-2012 final report. National Board of Antiquities, vol 2. National Board of Antiquities, Helsinki

Austin BT, Bateman J, Jeffrey S, Mitcham J, Niven K (2009) Marine remote sensing and photogrammetry: a guide to good practice. VENUS Virtual Exploration of Underwater Site. Information Society Technologies http://guides.archaeologydataservice.ac.uk/ g2gp.pdf?page=VENUS_Toc\&xsl=test.xsl\&ext=.pdf. Accessed 5 Aug 2018

Balletti C, Beltrame C, Costa E, Guerra F, Vernier P (2015) Photogrammetry in maritime and underwater archaeology: two marble wrecks from Sicily. In: Pezzati L, Targowski P (eds) Proceedings SPIE 9527: optics for arts, architecture, and archaeology V, 95270M (30 June 2015). SPIE Optical Metrology, Munich, pp 1-12. https://doi.org/10.1117/12.2184802

Bass GF (1966) Archaeology under water. Praeger, New York

Bass GF, Throckmorton P, Taylor JP, Hennessy JB, Shulman AR, Buchholz H-G (1967) Cape Gelidonya: a Bronze Age shipwreck. Trans Am Philos Soc 57(8):1-177. https://doi.org/10.2307/1005978

Bates CR, Lawrence M, Dean M, Robertson P (2011) Geophysical methods for wreck-site monitoring: the Rapid Archaeological Site Surveying and Evaluation (RASSE) programme. Int J Naut Archaeol 40(2):404-416. https://doi.org/10.1111/j.1095-9270.2010.00298.x

Bruno F, Lagudi A, Barbieri L, Muzzupappa M, Ritacco G, Cozza A, Cozza M, Peluso R, Lupia M, Cario G (2016) Virtual and augmented reality tools to improve the exploitation of underwater archaeological sites by diver and non-diver tourists. In: Ioannides M, Fink E, Moropoulou A, Hagedorn-Saupe M, Fresa A, Liestøl G, Rajcic V, 
Grussenmeyer P (eds) Digital heritage. Progress in cultural heritage: documentation, preservation, and protection, EuroMed 2016. Lecture notes in computer science, vol 10058. Springer, Cham, pp 269-280. https://doi.org/10.1007/978-3-319-48496-9_22

Bruno F, Lagudi A, Ritacco G, Philpin-Briscoe O, Poullis C, Mudur S, Simon B (2017) Development and integration of digital technologies addressed to raise awareness and access to European underwater cultural heritage: an overview of the H2020 i-MARECULTURE project. Oceans. 2017 - Aberdeen. Aberdeen: 1-10. https://doi. org/10.1109/OCEANSE. 2017.8084984? src=document

Calder BR, Forbes B, Mallace D (2007) Marine heritage monitoring with high-resolution survey tools: Scapa flow 2001-2006. In: US hydrographic conference, pp 1-23

Campana S (2014) 3D modeling in archaeology and cultural heritage - theory and best practice. In: Campana S, Remondino F (eds) 3D recording and modelling in archaeology and cultural heritage. BAR International Series 2598. British Archaeological Reports, pp 7-12

Campana S (2017) Drones in archaeology: state-of-the-art and future perspectives. Archaeol Prospect 24(4):275-296. https://doi. org/10.1002/arp.1569

Caporaso A (2017) A dynamic processual maritime archaeological landscape formation model. In: Caporaso A (ed) Formation processes of maritime archaeological landscapes, When the land meets the sea book series (ACUA). Springer, Cham, pp 7-31. https://doi. org/10.1007/978-3-319-48787-8

Castro F, Drap P (2017) A arqueologia marítima e o futuro-maritime archaeology and the future. Revista Latino-Americana de Arqueologia. For Hist 11:40-55

Chapman P, Bale K, Drap P (2010) We all live in a virtual submarine. IEEE Comput Graph Appl 30(1):85-89. https://doi.org/10.1109/ MCG.2010.20

Cooper JP, Wetherelt A, Eyre M (2018) From boatyard to museum: 3D laser scanning and digital modelling of the Qatar Museums watercraft collection. Int J Naut Archaeol 47(2):1-24. https://doi. org/10.1111/1095-9270.12298

Discamps E, Muth X, Gravina B, Lacrampe-Cuyaubère F, Chadelle JP, Faivre JP, Maureille B (2016) Photogrammetry as a tool for integrating archival data in archaeological fieldwork: examples from the Middle Palaeolithic sites of Combe-Grenal, Le Moustier, and Regourdou. J Archaeol Sci 8:268-276. https://doi.org/10.1016/j. jasrep.2016.06.004

Doneus M, Doneus N, Briese C, Pregesbauer M, Mandlburger G, Verhoeven GJ (2013) Airborne laser bathymetry—detecting and recording submerged archaeological sites from the air. J Archaeol Sci 40(4):2136-2151. https://doi.org/10.1016/j.jas.2012.12.021

Doneus M, Miholjek I, Mandlburger G, Doneus N, Verhoeven GJ, Briese C, Pregesbauer M (2015) Airborne laser bathymetry for documentation of submerged archaeological sites in shallow water. Int Arch Photogramm, Remote Sens Spat Inf Sci Arch 40(5W5):99107. https://doi.org/10.5194/isprsarchives-XL-5-W5-99-2015

Drap P, Seinturier J, Scaradozzi D, Gambogi P, Long L, Gauch F (2007) Photogrammetry for virtual exploration of underwater archaeological sites. Proceedings of the 21 st International Symposium of CIPA, Athens, Greece, 1-6 October 2007, 6 pp

Drap P, Merad DD, Mahiddine A, Seinturier J, Peloso D, Boï J-M, Chemisky B, Long L (2013) Underwater photogrammetry for archaeology: what will be the next step? Int J Herit Digit Era 2(3):375-394. https://doi.org/10.1260/2047-4970.2.3.375

Eriksson N, Rönnby J (2017) Mars (1564): the initial archaeological investigations of a great 16th-century Swedish warship. Int J Naut Archaeol 46(1):92-107. https://doi.org/10.1111/1095-9270.12210

Europeana (2018) https://www.europeana.eu. Accessed 23 July 2018

Flatman J (2007) The origins and ethics of maritime archaeology part I. Public Archaeol 6(2):77-97. https://doi.org/10.1179/1753553 07X230739
Frankland T, Earl G (2012) Authority and authenticity in future archaeological visualisation. In: Hohl M (ed) Making visible the invisible: art, design and science in data visualisation. University of Huddersfield, Huddersfield, pp 62-68

Gaffney VL, Thomson K, Fitch S (eds) (2007) Mapping Doggerland: the Mesolithic landscapes of the Southern North Sea. Archaeopress, Oxford

Galeazzi F, Callieri M, Dellepiane M, Charno M, Richards J, Scopigno R (2016) Web-based visualization for 3D data in archaeology: the ADS 3D viewer. J Archaeol Sci 9:1-11. https://doi.org/10.1016/j. jasrep.2016.06.045

Gately I, Benjamin J (2018) Archaeology hijacked: addressing the historical misappropriations of maritime and underwater archaeology. J Marit Archaeol 13(1):15-35. https://doi.org/10.1007/ s11457-017-9177-8

Green J (2004) Maritime archaeology: a technical handbook, 2nd edn. Elsevier, London

Gutowski M, Malgorn J, Vardy M (2015) 3D sub-bottom profilinghigh resolution 3D imaging of shallow subsurface structures and buried objects. In: Proceedings of MTS/IEEE OCEANS 2015. Genova, Discovering Sustainable Ocean Energy for a New World, pp 1-7

Harzing AW (2007) Publish or Perish. https://harzing.com/resources/ publish-or-perish. Accessed 7 Aug 2018

Haydar M, Maidi M, Roussel D, Drap P, Bale K, Chapman P (2008) 'Virtual exploration of underwater archaeological sites: visualization and interaction in mixed reality environments. In: Ashley M, Hermon S, Proenca A, Rodriguez-Echavarria K (eds) Proceedings of VAST: international symposium on virtual reality, archaeology and intelligent cultural heritage. The Eurographics Association, pp 141-148. https://doi.org/10.2312/VAST/VAST08/141-148

Henderson JC, Pizarro O, Johnson-Roberson M, Mahon I (2013) Mapping submerged archaeological sites using stereo-vision photogrammetry. Int J Naut Archaeol 42(2):243-256. https://doi. org/10.1111/1095-9270.12016

Historic England (2017) Photogrammetric applications for cultural heritage: guidance for good practice. Swindon

Huggett J (2017) The apparatus of digital archaeology. Internet Archaeol (44). https://doi.org/10.11141/ia.44.7

iMareCulture (2018) http://imareculture.weebly.com. Accessed 1 Aug 2018

Jeffrey S (2012) A new digital dark age? collaborative web tools, social media and long-term preservation. World Archaeol 44(4):553-570. https://doi.org/10.1080/00438243.2012.737579

Johnson-Roberson M, Bryson M, Friedman A, Pizarro O, Troni G, Ozog P, Henderson JC (2017) High-resolution underwater robotic vision-based mapping and three-dimensional reconstruction for archaeology. J Field Robot 34:625-643. https://doi.org/10.1002/ rob. 21658

Kenderdine S (1998) Sailing on the silicon sea: the design of a virtual maritime museum. Arch Mus Inform 12(1):17-38

Liarokapis F, Kouřil P, Agrafiotis P, Demesticha S, Chmelík J, Skarlatos D (2017) 3D Modelling and mapping for virtual exploration of underwater archaeology assets. Int Arch Photogramm, Remote Sens Spat Inf Sci Arch XLII-2/W3(March):425-431. https://doi. org/10.5194/isprs-archives-XLII-2-W3-425-2017

Lin SS (2003) Lading of the Late Bronze Age ship at Uluburun. MA thesis, Texas A\&M University

Mahiddine A, Seinturier J, Peloso D, Bö̈ J-M, Drap P, Merad D D, Long L (2012) Underwater image preprocessing for automated photogrammetry in high turbidity water: an application on the Arles-Rhone XIII Roman wreck in the Rhodano river, France. In: Proceedings of the 18th international conference on virtual systems and multimedia (VSMM 2012), Milan, Italy, 2-5 September 2012. Virtual Systems in the Information Society, pp 189-194. https://doi. org/10.1109/VSMM.2012.6365924 
Mahon I, Pizarro O, Johnson-Roberson M, Friedman A, Williams SB, Henderson JC (2011) Reconstructing Pavlopetri: mapping the world's oldest submerged town using stereo-vision. In: Proceedings of the IEEE international conference on robotics and automation, 9-13 May 2011. IEEE, Shanghai, pp 2315-2321. https://doi. org/10.1109/ICRA.2011.5980536

Martin P (2011) Conclusion: future directions. In: Catsambis A, Ford B, Hamilton DL (eds) The Oxford handbook of maritime archaeology. Oxford University Press, Oxford, pp 1085-1101. https://doi. org/10.1093/oxfordhb/9780199336005.001.0001

McCarthy J (2014) Multi-image photogrammetry as a practical tool for cultural heritage survey and community engagement. J Archaeol Sci 43:175-185. https://doi.org/10.1016/j.jas.2014.01.010

McCarthy JK, Benjamin J (2014) Multi-image photogrammetry for underwater archaeological site recording: an accessible, diver-based approach. J Marit Archaeol 9(1):95-114. https://doi.org/10.1007/ s11457-014-9127-7

Menna F, Agrafiotis P, Georgopoulos A (2018) State of the art and applications in archaeological underwater $3 \mathrm{D}$ recording and mapping. J Cult Herit 2017:1-18. https://doi.org/10.1016/j. culher.2018.02.017

Micheletti N, Chandler JH, Lane SN (2015) Structure from motion (SfM) photogrammetry. British Society for Geomorphology. Geomorphol Tech 2(2):12

Missiaen T, Evangelinos D, Claerhout C, De Clercq M, Pieters M, Demerre I (2018) Archaeological prospection of the nearshore and intertidal area using ultra-high resolution marine acoustic techniques: results from a test study on the Belgian coast at Ostend-Raversijde. Geoarchaeology 33(3):386-400. https://doi. org/10.1002/gea.21656

Morales R, Keitler P, Maier P, Klinker G (2009) An underwater augmented reality system for commercial diving operations. Oceans 2009(1-3):794-801

Morgan C, Wright H (2018) Pencils and pixels: drawing and digital media in archaeological field recording. J Field Archaeol 43(2):116. https://doi.org/10.1080/00934690.2018.1428488

Muckelroy K (1978) Maritime archaeology. Cambridge University Press, Cambridge

Oxford English Dictionary (2018) Oxford Dictionaries. https://www. oxforddictionaries.com/. Accessed 23 July 2018

Pacheco-Ruiz R, Adams J, Pedrotti F (2018) 4D modelling of low visibility underwater archaeological excavations using multisource photogrammetry in the Bulgarian Black Sea. J Archaeol Sci 100:120-129. https://doi.org/10.1016/j.jas.2018.10.005

Passaro S, Budillon F, Ruggieri S, Bilotti G, Cipriani M, Di Maio R, D'Isanto C, Giordano F, Leggieri C, Marsella E, Soldovieri MG (2009) Integrated geophysical investigation applied to the definition of buried and outcropping targets of archaeological relevance in very shallow water. Il Quaternario (Ital J Quat Sci) 22(1):33-38

Philbin-Briscoe O, Simon B, Mudur S, Poullis C, Rizvic S, Boskovic D, Katsouri I, Demesticha S, Skarlatos D (2017) A serious game for understanding ancient seafaring in the Mediterranean Sea. In: Proceedings of the 2017 9th international conference on virtual worlds and games for serious applications, Athens, 6-8 September 2017, pp 1-5. https://doi.org/10.1109/VS-GAMES.2017.8055804

Plets RMK, Dix JK, Best AI (2008) Mapping of the buried Yarmouth roads wreck, Isle of Wight, UK, using a chirp subbottom profiler. Int J Naut Archaeol 37(2):360-373. https://doi. org/10.1111/j.1095-9270.2007.00176.x

Plets RMK, Dix JK, Adams JR, Bull JM, Henstock TJ, Gutowski M, Best AI (2009) The use of a high-resolution 3D Chirp sub-bottom profiler for the reconstruction of the shallow water archaeological site of the Grace Dieu (1439), River Hamble, UK. J Archaeol Sci 36(2):408-418. https://doi.org/10.1016/j.jas.2008.09.026

Quinn R, Boland D (2010) The role of time-lapse bathymetric surveys in assessing morphological change at shipwreck sites. J Archaeol Sci 37(11):2938-2946
Quinn R, Smyth TAG (2017) Processes and patterns of flow, erosion, and deposition at shipwreck sites: a computational fluid dynamic simulation. Archaeol Anthropol Sci 2017:11. https://doi. org/10.1007/s12520-017-0468-7

Quinn R, Bull JM, Dix JK, Adams JR (1997) The Mary Rose sitegeophysical evidence for palaeo-scour marks. Int J Naut Archaeol 26(1):3-16. https://doi.org/10.1111/j.1095-9270.1997.tb01309.x

Ranieri G, Loddo F, Godio A, Stocco S, Cosentino PL, Capizzi P, Messina P, Savini A, Bruno V, Cau MA, Orfila M (2010) Reconstruction of archaeological features in a Mediterranean coastal environment using non-invasive techniques. In: Making history interactive: computer applications and quantitative methods in archaeology: proceedings of the 37th international conference, Williamsburg, Virginia, USA, 22-26 March. CAA2009. BAR International Series S2079. 19(2000), pp 330-337

Remondino F, Nocerino E, Toschi I, Menna F (2017) A critical review of automated photogrammetric processing of large datasets. Int Arch Photogramm, Remote Sens Spat Inf Sci XLII-2/W5:591-599. https://doi.org/10.5194/isprs-archives-XLII-2-W5-591-2017

Rowland C, Hyttinen K (2017) Photogrammetry in depth: revealing HMS Hampshire. In: Bowen JP, Diprose G, Lambert N (eds) Proceedings of electronic visualisation and the arts (EVA 2017), London, UK, 11-13 July 2017. EVA, London, pp 358-364. https:// doi.org/10.14236/ewic/EVA2017.72

Rule N (1989) The Direct Survey Method (DSM) of underwater survey, and its application underwater. Int J Naut Archaeol 18(2):157-162. https://doi.org/10.1111/j.1095-9270.1989.tb00187.x

Sanders DH (2011) Virtual reconstruction of maritime sites and artifacts. In: Catsambis A, Ford B, Hamilton DL (eds) The Oxford handbook of maritime archaeology. Oxford University Press, Oxford, pp 305-326. https://doi.org/10.1093/oxfor $\mathrm{dhb} / 9780199336005.001 .0001$

Simyrdanis K, Papadopoulos N, Kim J-H, Tsourlos P, Moffat I (2015) Archaeological investigations in the shallow seawater environment with electrical resistivity tomography. Near Surf Geophys 13(6):601-611. https://doi.org/10.3997/1873-0604.2015045

Simyrdanis K, Papadopoulos N, Cantoro G (2016) Shallow off-shore archaeological prospection with 3-D electrical resistivity tomography: the case of Olous (Modern Elounda), Greece. Remote Sens 8(11):897. https://doi.org/10.3390/rs8110897

Simyrdanis K, Moffat I, Papadopoulos N, Kowlessar J, Bailey M (2018) 3D mapping of the submerged Crowie barge using electrical resistivity tomography. Int $\mathrm{J}$ Geophys:1-11. https://doi. org/10.1155/2018/6480565

Skarlatos D, Agrafiotis P, Balogh T, Bruno F, Castro F, Petriaggi BD, Demesticha S, Doulamis A, Drap P, Georgopoulos A, Kikillos F, Kyriakidis P, Liarokapis F, Poullis C, Rizvic S (2016) Project iMARECULTURE: advanced VR, iMmersive serious games and augmented REality as tools to raise awareness and access to European underwater CULTURal heritagE. In: Ioannides $M$ et al (eds) Digital heritage: progress in cultural heritage: documentation, preservation, and protection, EuroMed 2016. Lecture notes in computer science, vol 10058. Springer, Cham, pp 805-813. https://doi. org/10.1007/978-3-319-48496-9_64

Sketchfab (2018) https://sketchfab.com. Accessed 23 July 2018

Tanner P (2012) The application of 3D laser scanning for recording vessels in the field. Naut Archaeol Soc Newsl: 1-4

The Thistlegorm Project (2018) The Thistlegorm project: an archaeological survey of the SS Thistlegorm, Red Sea, Egypt. http://thethistlegormproject.com. Accessed 1 Aug 2018

The UNITWIN Network (2018) http://www.underwaterarchaeology. net. Accessed 1 Aug 2018

Van Damme T (2015a) Computer vision photogrammetry for underwater archaeological site recording: a critical assessment. MA thesis, University of Southern Denmark

Van Damme T (2015b) Computer vision photogrammetry for underwater archaeological site recording in a low-visibility environment. 
Int Arch Photogramm Remote Sens Spat Inf Sci XL-5/W5:231-238. https://doi.org/10.5194/isprsarchives-XL-5-W5-231-2015

Vardy ME, Dix JK, Henstock TJ, Bull JM, Gutowski M (2008) Decimeter-resolution 3D seismic volume in shallow water: a case study in small-object detection. Geophysics 73(2):B33-B40

Warren D, Wu C-W, Church RA, Westrick R (2010) Utilization of multibeam bathymetry and backscatter for documenting and planning detailed investigations of deepwater archaeological sites. In: Proceedings of Offshore Technology Conference, 3-6 May, Houston, pp 1-8. https://doi.org/10.4043/20853-MS

Woods A (2013) 3D or 3-D: a study of terminology, usage and style. Eur Sci Editing 39(3):59-62
Yamafune K (2016) Using computer vision photogrammetry (Agisoft Photoscan) to record and analyze underwater shipwreck sites. PhD dissertation, Texas A\&M University

Yamafune K, Torres R, Castro F (2016) Multi-image photogrammetry to record and reconstruct underwater shipwreck sites. J Archaeol Method Theory 24(3):703-725. https://doi.org/10.1007/ s10816-016-9283-1

Yamashita S, Zhang X, Rekimoto J (2016) AquaCAVE: augmented swimming environment with immersive surround-screen virtual reality. In: Proceedings of the 29th annual symposium on user interface software and technology, pp 183-184. https://doi. org/10.1145/2984751.2984760

Open Access This chapter is licensed under the terms of the Creative Commons Attribution 4.0 International License (http://creativecommons.org/ licenses/by/4.0/), which permits use, sharing, adaptation, distribution and reproduction in any medium or format, as long as you give appropriate credit to the original author(s) and the source, provide a link to the Creative Commons licence and indicate if changes were made.

The images or other third party material in this chapter are included in the chapter's Creative Commons licence, unless indicated otherwise in a credit line to the material. If material is not included in the chapter's Creative Commons licence and your intended use is not permitted by statutory regulation or exceeds the permitted use, you will need to obtain permission directly from the copyright holder. 